\title{
LANGUAGE ECONOMY IN SHORT TEXT MESSAGES
}

Keywords: short text message, language economy, shortening strategies, contrastive study

\begin{abstract}
The purpose of this paper is to investigate some of the formal characteristics of the genre of the short text message, with a special focus on the concept of language economy, which typically underlies the use of this mode of communication. The subject of analysis are text messages in two languages, English and Polish, which are compared in terms of the methods of text shortening used by the two language systems. The elements studied include word clippings, vowel deletion, word-letter substitution, word-number substitution, spelling simplification, and pronoun deletion. The aim is to establish the preferred options in the two languages and identify reasons for such choices.
\end{abstract}

Used mainly in private communication, short text message language is an infrequent subject of study (cf. Thurlow and Brown 2003, Baron 2008). When analysing Computer Mediated Communication (CMC), a new channel of communication and for some even a new genre (cf. e.g. Crystal 2001) - researchers focus more on the language of electronic media in general, especially the language used in Instant Messaging, chatrooms or discussion lists, etc. (cf. Baron 2008). One of the most extensive studies devoted to short text message language and its numerous aspects to date is the book Txtng. The Gr8 Db8 written by Crystal (2008), which has served as the basis of my analysis. Interesting observations concerning the form and use of text messages, especially in the American and Japanese context, are to be found in Baron (2008). A brief analysis concerning the purpose as well as the formal characteristics of text messages is also provided by Biber and Conrad (2009). All refer to a paper by Thurlow (2003), one of the earliest studies on the subject, which offers useful information concerning the reasons for texting and the forms of text messages in British English. Besides, worth mentioning are also works by 
Ling $(2005,2007)$ on the use of text messages and predictive texting in Norwegian, as well as the analysis of text adaptations in short text messages found in Swedish by Hård af Segerstad (2002).

Texting may involve numerous linguistic phenomena. One of them are borrowings from one language into another, as e.g. borrowings from English into Polish (cf. Dąbrowska 2004), another the question of linguistic inventiveness (cf. Thurlow and Brown 2003, Crystal 2008) or the influence of texting and the CMC on the communicative patterns of youth and the decline of literacy (cf. Baron 2008). Moreover, its analysis may contribute to the discussion concerning specific registers (cf. Biber and Conrad 2009). Finally, as my paper will demonstrate, the analysis of text messages may provide interesting data concerning language economy. As Crystal (2008: 65) says, the keyboard was originally created not for texting, but for calculating, therefore communicating by means of messages written with the help of the keypad is not the most natural thing. Sending a text message costs money, so the longer the message, the more expensive it will be. Additionally, most mobile phones have a limited number of characters per text, usually around 160 (cf. Thurlow and Brown 2003). However, as Thurlow (2003) claims, the average length of text messages in British English is only around 65 characters, and up to 46 in Norwegian (cf. Ling 2007). The primary consideration accounting for the limited length of text messages must therefore be that it is an uncomfortable and time-consuming activity (cf. Crystal 2008, Dąbrowska 2010). For this reason text message users have developed a number of abbreviation strategies. Linguistic shortening is not a new phenomenon in the context of the English language, it was, for instance, often observed and even commented upon publicly (in negative terms), e.g. in the period of the Restoration, as was the case with, for instance, Jonathan Swift (cf. Baugh and Cable 2002: 259-260, Crystal 2008: 51-52). To date, linguists have primarily analysed the shortening of text messages in the English medium (Thurlow and Brown 2003, Ling and Baron 2007, Baron 2008, Crystal 2008, Biber and Conrad 2009). There are also some data available in other languages, viz. in German (Döring 2002), Swedish (Hård af Segerstad 2002), and Norwegian (Ling 2005), however, their limited number and sometimes rather scanty characteristics may lead to the assumption that the same type of shortenings are to be observed in any language. As the following analysis will prove, however, identical strategies cannot be shared by all languages in which messages are composed, or may be shared to a different degree (cf. Crystal 2008). The purpose of this paper is thus to examine text messages written in English and in Polish in terms of the shortening strategies used, provide their classification and frequency, and find possible answers as to why certain choices are typically made or avoided in the two respective languages.

The following analysis was based on 100 examples of messages with at least one shortened element in them - 52 in English and 48 in Polish. Altogether 94 individual examples of various abbreviations were found in the Polish text messages, and as many as 184 in those written in English. In the case of the Polish messages they were all written by native speakers of Polish, friends, family, and colleagues (which immediately implies a certain degree of solidarity and informality, of which 
the shortening is a manifestation), aged between 25 and 60, whereas the messages written in English were generated by users of English as a first language (Great Britain, the USA), English as a second language (India, Kenya), and English as a foreign language (Poland, Ukraine, Romania). The discrepancy between the number of examples of shortening in each of the two languages, despite an almost identical number of sample messages, shows immediately that there is a much greater preference (as well as possibly linguistic means) to economise on the length of text messages in English rather than in Polish. It must be noted that while the English messages (65 of which were analysed in total) came from the period between Jan-May 2010 (i.e. 5 months only), it was necessary to examine the Polish messages over a period of 11 months (July 2009 - May 2010), which meant scanning as many as 230 messages, in order to find a more or less matching number of abbreviated texts. It is already at this point that we can see a difference between the two languages in terms of the options they offer as well as their users' strategies.

This paper is divided into a number of sections, each focusing on particular categories of shortenings appearing in the English and then in the Polish messages, respectively. An initial comparison of categories identified in the two groups indicates differences between them, and the detailed analysis attempts to establish reasons for the choices made. Additionally, after presentation of the classification some comments are offered on the subject of ethnic as well as gender preferences for the given types of abbreviations.

\section{Text messages in English}

\section{Clippings and contractions}

The most natural option for making words shorter is to clip or contract them, typically by cutting off the ending or the second part of the word, and more seldom also the beginning, or a middle part of it. English words of foreign origin tend to be longer than native Germanic vocabulary, and are the most likely candidates for clippings. This method can also be used with some parts of speech characterised by additional endings like adjectives and adverbs. The examples of clippings and contractions (17 of them) found in the material are represented by the following:

1. Some work tomo and then back to pune [tomorrow]

2. Looks like there is a long delay in your pol cell [Polish]

3. Now in a resto [restaurant]

4. Wrt dwn hotel add [address]

5. Hope all well $\boldsymbol{w i}$ [with] $\mathrm{u}$

6. xtra thx za vege [vegetarian]

7. will leave the other at the station if poss [possible]

8. Yes, all well, hotel right opp [opposite] museum

9. Yes, correct. In govt [government] schools it wud be the 2nd or 3rd lang [language]

10. tickets are approx [approximately] $£ 65$

11. Before you book $p l$ [please] give me the price 
12. $\boldsymbol{P l}$ [please] be safe sis [sister]

13. Don't know exact [exactly], but yr nephew $\operatorname{com} \boldsymbol{p}$ [computer] expert will. If not $\operatorname{comp}$ [computer] guys/shop by church

14. until $\boldsymbol{v}$ [very] late on Sunday eve [evening]

The above material contains examples of other types as well, but it can be seen that this group of abbreviations is still quite sizeable with 17 examples out of 184 altogether. As stated above, the words clipped and contracted would mainly include longer words of foreign origin, and thus among the words found here are examples such as address, approximately, computer, exactly, government, language, opposite, please, restaurant, vegetarian, with just a minimal number of Germanic vocabulary, such as evening, sister, tomorrow, and with. It can thus be seen that the trimming of the syllable or syllables significantly shortens the words and no doubt saves the sender the problem of possible mistakes with a complicated spelling, and, most importantly, contributes to the speed of message typing. The above examples appear to be quite typical words with high frequencies of use in the language, therefore their predominantly clipped form should not on the whole cause difficulties with their proper interpretation. In the case of a few, e.g. add and resto it is the context that will help the addressee decide what they refer to (cf. Crystal 2008). The presence of forms like tomo can be understandable on account of their length, whereas elements like $p l$ and $v$ may be explained by their high frequency. The word sis, on the other hand, is in fact more of a term of endearment as a form of address, rather than just a shortening, similar to other forms which are often subjected to the strategy of a clipping, e.g. bro, $m a, p a$, etc. This strategy is surely the simplest and least risky of all.

\section{Vowel omission}

The strategy of deleting sounds and notably vowels from long words results in forms which may be more difficult to decipher. It is therefore found with items of vocabulary which are more predictable due to their high frequency of use in language. As these collected examples (38 in all) show, vowel omission concerns mainly auxiliaries / function words and some set phrases:

1. I got your $\boldsymbol{m s g}$ [message] and 7 is fine.

2. Looks like there is a long delay in your pol cell $\boldsymbol{m s g s}$ [messages]

3. So u'll reach by $9 \boldsymbol{t h n}$ [then]. Wrt $\boldsymbol{d} \boldsymbol{w} \boldsymbol{n}$ [write down] hotel add

4. I m vry [very] sory

5. can u met me $\boldsymbol{n} \boldsymbol{w}$ [now] bqz after one hour I hve [have] 2 go out of Delhi

6. I $\boldsymbol{m}$ [am] in trffic [traffic]

7. We $\boldsymbol{r}$ [are] at lunch still $\boldsymbol{n d}$ [and] $\boldsymbol{w} \boldsymbol{l}$ [will] end late

8. $\boldsymbol{W l}$ [will] cal

9. Ya I $\boldsymbol{h} \boldsymbol{v}$ [have] to know exact no by 4.30 as cook $\boldsymbol{c m i n g}$ [coming]

10. pls [please] text me

11. so sorry u $\boldsymbol{c d n ' t}$ [couldn't] b with us 
12. $\boldsymbol{x t r a}$ [extra] thx [thanks] za vege

13. certainly $\boldsymbol{w} \boldsymbol{l}$ [will] $\boldsymbol{b}$ [be] $\boldsymbol{n}$ [in] $\boldsymbol{t} \boldsymbol{h}$ [touch] ... Hpy [happy] jrny [journey] u take Cr [care]

14. I look $f w d$ [forward] to seeing ur photo

15. OK 16.30 więc c u tmrw [tomorrow]

16. Mobile dischargd [discharged]

17. $\boldsymbol{g d}$ [good] mng. [morning]

With 46 items, this is certainly a considerably larger group than the previous one. The strategy itself is not new, either - it has long been observed (cf. Crystal 2008: 26-27) that it is relatively easy to decipher a message built out of consonants only, as they are the main message carriers, whereas it is in fact impossible to do so if we remove all the consonants and retain only vowels (Arabic or Hebrew words are spelled only with consonants). It can be seen that indeed the most popular items here are either words typically associated with the text message medium, as e.g. message, or simple functional vocabulary such as auxiliaries will, have, the linking word and, adverbs like tomorrow and now, and also such popular words as forward and morning. The remaining vocabulary most often comprises short words, as are, be, back, down, extra, from, good, how, in, touch, very, write, etc., where in most cases only one vowel has to be deleted, and therefore the message remains clear (it has to be added at this point that due to their length examples like $r, b, m$ can be classified as members of the vowel omission as well as the word-letter substitution category discussed below). With more complex and lesser-used words only one vowel gets deleted, viz. dischargd, cming or trffic. It can be concluded, therefore, that this strategy has its limitations; on the other hand, however, it may be fairly safely applied in the case of the English language, which tends to contain a large percentage of short, often monosyllabic words.

\section{Word-letter substitution}

This strategy appears to be related mainly to the above-mentioned fact, i.e. that the English language contains a large percentage of monosyllabic words. This makes it fairly easy to find words which sound like individual letters of the English alphabet, and at the same time makes it impossible for many other languages which use longer words and are additionally inflected (i.e. receive various endings), to utilise this strategy. The list of examples (51) below shows, though, that the words which typically get substituted this way are fairly limited in number:

1. will certainly pray $4 \boldsymbol{u}$ [you]

2. When $\boldsymbol{u}$ [you] come it wud be ideal if $\boldsymbol{u}$ [you] came at least two days before the conference

3. $\boldsymbol{U}$ [you] must come!

4. This $\boldsymbol{s}$ [is] my swiss mobile. Let me know if $\boldsymbol{u}$ [you] get this text alright

5. These 'cannot be displayed' msgs frm $\boldsymbol{u}$ [you] shud $\boldsymbol{b}$ [be] sum icons.

6. Ok wish u [you] hapy flight. Hope $\boldsymbol{c}$ [see] $\boldsymbol{u}$ [you] sun. 
7. can $\boldsymbol{u}$ [you] meet me nw bqz after one hour I hve 2 go out of Delhi. Re $\boldsymbol{u}$ [you] in $\boldsymbol{d}$ [the] hotel I $\boldsymbol{m}$ [am] near of Sunny. I sent $\boldsymbol{u}$ [you] sms this morning hve $\boldsymbol{u}$ [you] got?

8. We $\boldsymbol{r}$ [are] at lunch still nd wl end late. Wl cal in $\boldsymbol{d}$ [the] evening

9. we $\boldsymbol{r}$ [are] going out at friends place for lunch...

10. so sorry $\boldsymbol{u}$ [you] cdn't $\boldsymbol{b}$ [be] with us. But it seems $\boldsymbol{u}$ [you] had a lot on.

11. Go 4 help, they $\boldsymbol{r}$ [are] nice

12. OK 16.30 więc $\boldsymbol{c}$ [see] $\boldsymbol{u}$ [you] tmrw

13. $\boldsymbol{c}$ [see] $\boldsymbol{u}$ [you] tonite

14. $\boldsymbol{C u}$ [see you] in Geneva

15. $\boldsymbol{R}$ [are] $\boldsymbol{u}$ [you] back in delhi? How was $\boldsymbol{d}$ [the] trip?

It can be seen that with as many as 51 examples of this strategy the variety of options is in fact very small, as it comprises only 7 different elements. The most frequent one, which seems to have become almost an officially acknowledged marker of the electronic code is the second person pronoun $u$. Indeed, not everyone uses it, and at times some inconsistencies can be seen, as in "its still preferable for $u$ to come to $\mathrm{X}$ on $15^{\text {th }}$ evening, but up to $u$ when $u$ can come. Before you book pl give me the price;" however, many text message senders have accepted it so much that they have also begun forming the possessive $u r$ or even the future form $u$ 'll. One of the most widely used markers of the short text message code is the sequence of word-letter substitutions $c u$ (sometimes also spelt as one word) - the element was recorded 5 times among the analysed examples. Some bolder text message users also risk less typical word-letter substitutions in a sentence, and not in such set phrases as $c u$, i.e. words like $b$ 'be', $r$ 'are', $m$ 'am', and $d$ 'the'. The use of $s$ for 'is' may in fact be just a misprint, but it may also be used as a shortening, although based, similarly as $m$ and $d$, only on partial homophony (paronomasia). The use of $d$ for 'the', although not matching the sound of the word in Standard English exactly, is an example of a regional pronunciation of the sound, here illustrating the Indian pronunciation of the word (cf. Crystal 2008).

\section{Word-number substitution (logograms)}

One of strategies typically enumerated in publications concerning the use of English in electronic media, and one that no doubt adds a special flavour to electronic language, is that of substituting a whole word with a single numeral. Besides the use of the word-letter substitutions discussed above, word-number substitutions are mainly responsible for the fact that electronic communication is treated as a unique form of written language. This strategy was not, however, all too frequently used in the collected samples (7 examples):

1. Hi X, just 2 [to] let you know im thinking of you

2. will certainly pray 4 [for] u. hope 2 [to] be in XXX

3. I hve 2 [to] go out of Delhi

4. which time u hve flight $2 \mathrm{mrw}$ [tomorrow] 
5. Go 4 [for] help, they $\mathrm{r}$ nice

6. hope $\mathrm{u}$ all had a fantastic new year and your hangovers were not 2 [too] bad. Iv had a couple of days off 2 [to] rest

The examples show us clearly that the number of options here is limited. The most frequently used figures are naturally 2 for the infinitival marker to, an Old English preposition to in tomorrow or possibly the adverb too; and the numeral 4 for the preposition for. One other option which may be found in the electronic language, though it did not appear here, is the figure 8, typically found in the word great gr8. Thus, as imaginative as the strategy is, it is not very helpful or very widespread.

\section{Non-standard spelling}

A strategy involving the modification of the spelling of words is yet another one quite often used by message senders. Unlike in other languages, e.g. Polish, where orthographic norms are to a large extent mandatory, and text message users do not as a rule flout them for the sake of shortening a message, the English language has a long tradition of spelling simplification reforms (e.g. Mulcaster or Hart in the $16^{\text {th }} \mathrm{c}$., Webster in the $18^{\text {th }} \mathrm{c}$. or Pitman and Ellis in the $19^{\text {th }} \mathrm{c}$. cf. Baugh and Cable 2002), and the fact that someone spells a word differently, thereby making the word shorter and less complicated, does not necessarily mean the person is not well educated (cf. Crystal 2008). The category is represented by 22 examples in all:

1. it $\boldsymbol{w u d}$ [would] be ideal if u came at least two days before

2. msgs frm u shud [should] b sum [some] icons.

3. thanx [thanks] for call

4. wish u hapy flight. Hope c u sun [soon]

5. gud [good] morning can u met me nw bqz after one hour I hve 2 go out of Delhi

6. Much luv [love]

7. Gud [good] morning X I m in trffic I wil there 10:00 am

8. Hi X gud [good] evening ... U tel [tell] me ur flight time

9. can they tel [tell] u by $4 \mathrm{pm}$ pls

10. wil [will] be bk by $4.30 \mathrm{pm}$

11. In govt schools it wud [would] be the 2nd or 3rd lang

12. c u tonite [tonight]

13. I m vry sory [sorry]

14. don't wory [worry] u wil [will] reach airport on time

15. So sory [sorry] but we have to refuse. Wl cal [call] in d evening

The 22 elements may broadly be divided into a group with simplification of vowels (the more typical one) and a group with simplification of consonants. Among the words manifesting changes of vowels, the most frequent ones are would, good, should, soon, some and love. Such forms appear to be more risky inventions than modifications of the consonantal type, which basically involve 
only a consonant deletion or the simplification of geminated spellings, as in will, tell, call, sorry, happy. They may occasionally be more complex and make use of a substitution of two or three letters by one with an equivalent sound, e.g. tonight tonite or thanks - thanx. These two are used in electronic communication so often that they have largely become conventionalised.

\section{Deletion of pronouns and auxiliaries}

Analysis of the collected examples demonstrates that strategies of shortening and simplifying text messages go beyond the level of spelling, to which all the above categories, except for the first one (clippings and contractions) belong. The remaining two types appear to also involve the level of grammar. This strategy, which is likewise quite characteristic of the casual as well as the intimate style levels, and also of slang reflected in writing, is that of pronoun deletion when in the position of the subject, typically the first person singular (cf. Joos 1959), as otherwise some confusion as to the referent might result, and occasionally of an auxiliary dropping in complex verb forms as well. This group consists of 19 examples:

1. Looks [it looks] like there is a long delay in your pol cell msgs. Hope [I hope] you reached safe and happy

2. slept [I slept] just enough. Could [I could] not charge cell till now

3. Wish [I wish] u hapy flight. Hope [I hope] c u sun.

4. $\quad W l[I$ will] cal $\mathrm{u}$ in $\mathrm{d}$ evening

5. $\boldsymbol{A} \boldsymbol{m}[\mathrm{I}$ am] afraid I didn't see ur msg until v late on Sunday eve. Hope [I hope] all well wi u.

6. will [I will] send an e-mail tomorrow

7. Have [have you a] time to meet?

8. will [I will] leave the other at the station if poss

9. Am [I am] staying here tonight

10. Going [I am going] there in a bit

11. Sounds [it sounds] like u $\mathrm{r}$ having the adventure of a life time

12. Back [I am back] from Wales

13. Just landed [I have landed]

This fairly numerous group mainly involves the deletion of the personal pronoun $I$, as in I will, I am, I could, I wish, I slept, I hope or it in forms like it sounds, it looks, thereby making the above examples subjectless sentences, unacceptable in formal Standard English. Occasionally, the chunks deleted can be a combination of a pronoun and an auxiliary, where, for instance, there is a reference to some past activity just completed, i.e. I have, as in I have just landed or a structure with the copula be, e.g. I am back or be as an auxiliary verb, as in I am going. There is also an example of a grammatically simplified question Have you a time to meet, where the subject you is deleted. It must be noted that this method allows for quite a considerable saving of text space, and has been widely accepted in informal language, hence its visible popularity. 


\section{Apostrophe deletion}

Yet another option of saving time and space while texting (although admittedly not to be compared in terms of space saving to the one above) which also involves the field of grammar is the deletion of the apostrophe, mainly in the contraction of pronouns and auxiliary verbs, and occasionally in genitive formations with nouns. Indeed, the space saved this way is minimal, therefore it may rather be seen as getting rid of a redundant feature of spelling. The incorrect spelling with the apostrophe omission in a form like it's can potentially be misleading. However, the context should mostly help disambiguate the meaning (cf. Thurlow and Brown 2003). This strategy is illustrated by 8 examples:

1. Hi X, just 2 let you know im [I'm] thinking of you

2. Oh my god X iv [I've] just seen the news

3. Its [it's] there!

4. Hi X its [it's] Y

5. its [it's] terrible

6. its [it's] still preferable for u to come to Sheffield

7. Hi guys im [I'm] back in the land of the living

8. Hi X my friend [friend's] name is Y

This group is certainly not very sizable. The most frequent instance is the omission of the apostrophe in the contraction of it's (4 examples), the others are I'm and I've (with an additional simplification of spelling) as well as one example of the nominal genitive, i.e. friend's name, in which case the entire genitive suffix 's is deleted. The presence of this type of shortening has to be acknowledged, yet its popularity seems to be surprisingly low in comparison with the results found by Baron (2008).

\section{Text messages in Polish}

\section{Clippings and contractions}

When the above plethora of options used by senders of texts in English is compared to the examples recorded in Polish, a striking difference is immediately seen. Among the analysed examples it is in fact possible to identify a maximum two types of strategies, and the first of them - the use of clippings and contractions - by far outnumbers the other. As many as 84 elements out of 94 belong to this category, which is a much greater number than that of the corresponding group of English messages, leaving the remaining strategy of the two above-mentioned ones almost unnoticeable (10 examples). With so many items it is much harder to identify typical examples within this group, as it comprises a great variety of individual words. However, on closer examination it is possible to subdivide this large number into certain subgroups which are enumerated below. 
- conventional clippings and contractions (44 examples)

1. Więc we $\boldsymbol{c} z \boldsymbol{w}$ [artek] o 13.30 niem[iecki]-ang[ielski]. - 'So on Thurs at 1.30 German-English'

2. X ile pytań $\mathrm{z}$ hist [orii] j[ęzyka] $\boldsymbol{a} \boldsymbol{n}$ [ielskiego] na $\boldsymbol{e g z}$ [amin] chcesz sformułować? - ' $\mathrm{X}$, how many questions in the history of the English language do you want to formulate for the exam?'

3. Może znajdziesz przed wyjazdem czas na kawę np. we $\boldsymbol{w} t$ [orek] lub śr[odę]? 'Do you think you will find some time for a coffee before your trip, e.g. on Tues or Wed?'

4. Ja jestem gotów na spotk. w pon[niedziałek] lub we $\boldsymbol{w} \boldsymbol{t}[\mathrm{orek}]$ - 'I'm ready to meet on Mon or Tue'

5. Ale dziś $\mathrm{X}$ jest pierwszy raz w $\mathrm{X}$ a w niedz[ielę] mają jakieś szkolenie - 'But it is X's first time there today, and they have some training on Sun'

6. Jakoś się nie czuję bojowo przed tym egz[aminem]... w pon.[niedziałek] mam poprawki - 'Somehow I'm not feeling the daring spirit before this exam... I have re-sits on Mon'

7. Ja jutro nie dam rady, w $\boldsymbol{c} \boldsymbol{z} \boldsymbol{w}$ [artek] rano zdaję $\boldsymbol{j}[$ [ęzyk] $\boldsymbol{a} \boldsymbol{\boldsymbol { n }} \boldsymbol{g}[\mathrm{ielski}]$ - 'I can't tomorrow, I have my English exam on Thurs'

8. Ja w $\boldsymbol{c} z \boldsymbol{w}$. [artek] wieczorem jadę do $\mathbf{W a}[$ rsza] $\boldsymbol{w} \boldsymbol{y}$ - 'I'm going to Warsaw on Thurs evening'

9. My po 3 tyg. [odniach] zwiedzania mamy dość. - 'After three weeks of sightseeing we are exhausted'

10. Dzięki za info[rmację] - 'Thanks for the information'

11. Spoko[jnie], czyli do jutra - 'Relax, till tomorrow then'

12. Pozdro[wienia] $\times 2$ - 'greetings'

13. Pozdr[owienia]/[awiam] $\times 12$ - 'greetings/I'm sending you my greetings'

Although the Polish language does not favour clippings and contractions as much as English does, there are some shortenings which have functioned in the language for many years on account of their frequency of use, especially in the educational context (e.g. they can be found in various documents). These examples will include firstly the shortened names of the days of the week, typically clipped to the 2-3 first letters, which are here represented by: pon, $w t, s$, $c z w$, niedz-poniedziałek, wtorek, środa, czwartek, niedziela (there is also pt, but it will be classified elsewhere), as well as the word tyg. (tydzien - in locative singular tygodniu) - the week itself. The other typical examples are names of school subjects such as hist (historia) and names of languages, here illustrated by (j.) ang (angielski) and (j.)niem. (niemiecki). Moreover, there are other items of vocabulary linked with education, as egz (egzamin) and odp (odpowiedź). Other than these, one can also include some items of informal language or slang here, typically heard in the language of youth, namely info (informacja) and spoko (spokojnie). To this group also belong the names of two cities Wawa (Warszawa) (the middle syllable missing) and Krak (Kraków), both of which have long been in use in informal language. Last but certainly not least, a new 
convention which has developed specifically in connection with the SMS language of users of Polish is a leave-taking formula (besides another option to be mentioned in a different category), viz. pozdr(o), which may either come from the plural noun pozdrowienia or the verb in the $1^{\text {st }}$ person singular pozdrawiam. As the examples of conventionalised abbreviations tend to be widely recognised, they do not seem to be a frequent source of ambiguity.

- innovative clippings and contractions (40 examples)

1. Do zoba[czenia] $\times 3$ - 'see you'

2. $\boldsymbol{E} \boldsymbol{w}$ [entualnie], jeśli Ci bardziej pasuje - 'possibly, if it suits you better'

3. Myślę, że ewent [ualnie] drugi tydzień listopada - 'I think that possibly the second week of November'

4. Dzie[kuję]! Ja pozdr[awiam] Cię z $z \boldsymbol{i m n}$ [ego] X, choć te -8 st[opni] w por[ównaniu] z - 25 w Kra[kowie] jest ciepłem. Str[asznie] jednak marznę i $\boldsymbol{z a z d r}$ [oszczę] Ci ciepełka! $\boldsymbol{T r} z$ [y] $\boldsymbol{m}$ [aj] się dzielnie i rob $\boldsymbol{z d j}$ [ęcia]. C[ałuję]. X 'Thank you! I'm sending you my greetings from a cold X, although these -8 degrees in comparison with -25 in Cracow is warm. But I'm really freezing and I envy you the warmth! Hold on bravely and take photos. Kisses, X'

5. Spoko, program od dawna mam zainst[alowany]. Jeszcze raz dzięki za impr[ez]ę i miłego weekendu (:) - 'No problem, I've had this programme installed for a long time. Once again thanks for the party and have a nice weekend'

6. Sorry ze dopiero teraz odp[owiadam]. Miałam straszne ostat[nie] 2 dni... Niestety w pt jestem w pracy od rana do wiecz[ora]. - 'Sorry that I'm replying only now. The last two days were terrible. Unfortunately, on Fri I'm at work from morning till evening'

7. Wstępnie umówiliśmy się nie na najbliższy, a nast[ępny] tydzień - 'we have tentatively agreed to meet not this, but next week'

8. Serd [ecznie] dziękuję. Pozdr - 'Heartfelt thanks. Greetings'

9. przeglądałam te thumacz[enia] - ale pomysłowi! - 'I've looked through those translations - they are really inventive'

10. X potrzebuje to zabrać 7 wrze [śnia] więc chyba po twoim powrocie ok. 'X needs to take it on 7 Sept, so it should be OK after you've returned'

11. Cały sierpień ja zajmuję się $\boldsymbol{k a w}$ [iarnią], więc jestem. Dzięki za pozdr z X. 'I am looking after the coffee-shop for the whole of August, so I'm here. Thanks for your greetings from $\mathrm{X}^{\prime}$

The examples found in this subgroup, i.e. 40 items, contain forms which have a very low frequency in text messages or are complete innovations of a given individual user. Such examples are usually not very numerous in relation to the total length of the message - typically up to four items per message, although there might be some individual cases of users who made use of many more in one text, e.g. "Dzie[kuję]! Ja pozdr[awiam] Cię z zimn[nego] X, choć te -8 st w por[ównaniu] z -25 w Kra[kowie] jest ciepłem. Str[asznie] jednak marznę i zazdr[oszczę] Ci 


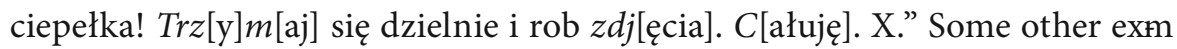
amples include, e.g., „Dopiero teraz doładowałem kom[órkę]. Ja jestem gotów na spotk[anie]. w pon[niedziałek] lub we $w t$ [orek]” or „Sorry że dopiero teraz odp[owiadam]. Miałam straszne ostat[nie]. 2 dni... Niestety w $p[$ ią $] t[$ ek] jestem w pracy od rana do wiecz[ora]." Altogether, my analysis has shown that a vast majority of abbreviated words in this section would typically lose the last two syllables and keep only the first one, e.g. dol[inie], dzie[kuję], kom[órkę], nast [ępny], pozdr[awiam], str[asznie], serd [ecznie], spotk[anie], wiecz[ora], zazdr[oszczę], zimn [ego], $z d j[e ̨ c i a], z o b a[c z e n i a]$, possibly on a subconscious assumption that one third of the word is already enough for someone to recognize it (cf. the concept of word redundancy in C-Tests developed in Germany at http://www.c-test.de). It has to be acknowledged, however, that most of these examples do not terminate at a syllable boundary, but mostly before a vowel, having attached the consonants of the syllable which follows to the preceding part which is kept (viz.pozdr[awiam] vs. the correct division into syllables po-zdra-wiam), or retaining just the first few consonants of the entire word (viz. odp [owiadam], str[asznie], $z d j$ [ęcia], etc.). This might, therefore, confirm the earlier conclusion that consonants are more essential than vowels to carry the meaning of words.

\section{Vowel/sound omission}

As mentioned above, the second and final group of abbreviations found in the Polish material, characterised by a deletion of sounds (particularly vowels) and an additional clipping, consists of only 10 elements:

1. Lot biuro i hotel $\boldsymbol{b} \boldsymbol{d} \boldsymbol{b}$ [bardzo dobre] - 'The flight, the office and the hotel were very good'

2. $\boldsymbol{P} \boldsymbol{z} \boldsymbol{d} \boldsymbol{r} \times 6$ [Pozdrawiam/Pozdrowienia] - 'Greetings'

3. Trzm [trzymaj] się dzielnie i rob zdj - 'Hold on bravely and take photos'

4. Niestety w $\boldsymbol{p t}$ [piątek] jestem w pracy od rana do wiecz. - 'Unfortunately, on Fri I'm at work from morning till evening'

5. Przekaż p. X żeby pilnie zapisała się na semin $\boldsymbol{m} \boldsymbol{g} \boldsymbol{r}$ [magisterskie] w usosie. 'Tell Miss X that she should urgently enroll for the MA seminar in USOS'

This very limited number shows that texters seem to dislike to use forms which consist of consonants (sometimes only some consonants of the original word) alone. Out of these the only one really well-accepted among message senders is the form $p z d r$ [pozdrawiam / pozdrowienia], which was found in 6 messages out of 10, and thus it can already be recognised as a new convention. The abbreviation pt (piatek) has also been long recognised outside the electronic context, likewise the forms $b d b$ (bardzo dobre), which is a typical way of writing the "very good" mark in the school system, and $m g r$, which is a frequent abbreviation referring to the MA studies / work / student. The only innovation which does not seem to be as yet generally shared is the form trzm [trzymaj się], a combination of both a clipping and a vowel omission. It can therefore be concluded that Polish users do not favour this form of 
shortening, most likely because Polish words tend to be polysyllabic, and therefore such abbreviations may cause ambiguity.

Having enumerated categories of shortenings it is still worth examining some additional sociolinguistic aspects of the abbreviated messages. Two important points have already been mentioned above, viz. 1) the fact that the use of shortenings is recorded twice as frequently in English as it is in Polish (and that it took twice as long to find a comparable number of messages with abbreviations in Polish as it did in English), and 2) the fact that a much greater variety of strategies of shortening messages was used by the authors of the English texts than by those writing in Polish. Additionally, concerning the English messages, which, as mentioned above, were generated by people of various nationalities, it is worth examining whether there might be any tendencies for a higher frequency of abbreviations for any particular group. A closer investigation actually proves that it is the Indian users who show special preference for this kind of strategy - among the 52 English messages collected as many as 26 were generated by Indian texters. The second largest group, which consisted of 16 messages, was that written by British senders. Finally, 5 English messages were produced by Polish users of English; the remaining ones were a miscellaneous group.

One more sociolinguistic variable worth examining is that of gender of the texters. Among the users of English 31 abbreviated messages out of 52 were written by male senders, with the remaining 21 created by female senders. In the case of the Polish language 20 out of 48 shortened messages altogether were written by female senders, which leaves us with 28 messages generated by male respondents. Although it is hard to generalise on the basis of this limited number of messages, the above results might indicate a slightly greater tendency to observe the standard rules of language use on the part of females, which means that it would be more typical of males to make use of shortening (and thus non-standard) strategies in text messages (cf. Baron's (2008) findings concerning gender in Instant Messaging).

\section{Concluding remarks}

- The above analysis has proved that both English and Polish make use of abbreviation strategies in short text messages, however, the two languages utilise different options.

- The English language offers many more possibilities of shortening than does Polish, due to which texters in Polish use abbreviations half as often as persons sending text messages in English.

- The strategy common to both languages is that of clipping, which in Polish may be further subdivided into conventional and innovative examples. The primary reason for the selection of this option appears to be the greater average length of Polish words, which, additionally, get further extended as the result of attaching inflectional endings. This feature of the Polish language is probably also the main reason why the Polish users are not able to use other strategies, such as 
word-number or word-letter substitutions, since the form of particular words is not fixed, but changes depending on their position and function in the sentence.

- The use of clippings is one of the less popular options found among the shortenings in English messages. The strategies used most frequently are word-letter substitutions and vowel omissions. However, since the former uses a limited number of items, although of high frequency (as $u, r, b$, etc.), it is the vowel omission strategy that offers users the greatest advantages. This option, found also in a handful of Polish examples, does not easily apply to Polish due to a greater length of words and their changeable endings. This, in turn, can cause a greater ambiguity in recognising the actual word, hence the need to combine it with a clipping.

- Two further strategies used in English, this time with fewer examples, are the non-standard spellings and the pronoun / auxiliary omission. The former appears to be more risky than the vowel omission, as here the variety of spellings may be much more dependent on the individual sender, whereas the vowel omission should as a rule produce the same result every time. The spelling of English words cannot in many cases be predicted. What is more, simplifying the spelling is not as profitable in terms of time- and space-saving as vowel omission is.

- As far as the omission of a pronoun or an auxiliary is concerned, the gain may not be very considerable as the omitted pronoun is typically the first person singular $I$, and occasionally the third person singular it, and thus both are short words. A greater advantage can be observed when the sentence is in the present perfect or present continuous tense, or else in a passive construction, where beside the pronoun the auxiliary is also omitted. This strategy is not of much use in Polish. Unlike English, Polish typically uses sentences with the understood subject if it is not expressed by a noun, and thus the gain in time and space is none. Regarding the apostrophe deletion, least preferred by English senders, this strategy has no application in Polish, as the Polish language does not make use of the apostrophe at all.

In summary, although the need to shorten text messages appears to be fairly universal, its frequency will vary from language to language. Also, the variety of possible strategies will depend on the features of each language, with the number of options more limited in the case of highly inflected languages than in the case of more analytic languages, such as, e.g., English. It may be concluded that the more analytic the language is, the more varied shortening strategies can be applied.

\section{References}

Baron N. 2008. Always on. Language in an online and mobile world. Oxford.

Baugh A.C., Cable T. 2002. A history of the English language. [ed. V]. Upper Saddle River, New Jersey.

Biber D., Conrad S. 2009. Register, genre and style. Cambridge.

Crystal D. 2001. Language and the Internet. Cambridge. 
Crystal D. 2008. Txtng. The Gr8 Db8. Oxford.

Dąbrowska M. 2004. English impact on the electronic media communication. - Duszak A., Okulska U. (eds.) Speaking from the margin: global English from a European perspective. Frankfurt am Main: 261-274.

Dąbrowska M. 2010. Functions of code-switching in electronic communication. - Jodłowiec M., Leśniewska J. (eds.) Ambiguity and the search for meaning: English and American studies at the beginning of the $21^{\text {st }}$ century. [vol. 2 Language and culture]. Kraków: 91-106.

Döring N. 2002. 'Kurzm. wird gesendet' - Abkürzungen und Akronyme in der SMS-Kommunikation. - Muttersprache. Vierteljahresschrift für deutsche Sprache 112 (2): 97-114.

Hård af Segerstad Y. 2002. Use and adaptation of written language to the conditions of computer-mediated communication. Göteborg.

Joos M. 1959. The five clocks. Bloomington.

Ling R. 2005. The sociolinguistics of SMS: An analysis of SMS use by a random sample of Norwegians. - Ling R., Pedersen P. (eds.) Mobile communications: Re-negotiation of the social sphere. London: 335-349.

Ling R., Baron N. 2007. Text messaging and IM: A linguistic comparison of American college data. - Journal of Language and Social Psychology 26 (3): 291-298.

\section{Internet sources}

C-Test [Der Sprachtest]. Available at http://www.c-test.de/deutsch/index.php

Ling R. 2007. The length of text messages and use of predictive texting: Who uses it and how much do they have to say. - AU TESOL working papers no. 4. Washington, D.C. Available at http://www.richardling.com/papers/2007_Text_prediction_paper.pdf.

Thurlow C., with Brown A. 2003. Generation Txt? The sociolinguistics of young people's text-messaging. - Discourse Analysis Online. Available at http://extra.shu.ac.uk/daol/ articles/v1/n1/a3/thurlow2002003.html. 